\begin{abstract}
Gonadal morphology and reproductive biology of the Black Anglerfish (Lophius budegassa) were studied by examining 4410 specimens collected between June 2007 and December 2010 in the northwestern Mediterranean Sea. Ovaries and testes presented traits common among fishes of the order Lophiiformes. Spawning occurred between November and March. Size at first maturity $\left(L_{50}\right)$ was $33.4 \mathrm{~cm}$ in total length (TL) for males and $48.2 \mathrm{~cm}$ TL for females. Black Anglerfish is a total spawner with group-synchronous oocyte development and determinate fecundity. Fecundity values ranged from 87,569 to 398,986 oocytes, and mean potential fecundity was estimated at 78,929 (standard error of the mean [SE] 13,648) oocytes per kilogram of mature female. This study provides the first description of the presence of 2-3 eggs sharing the same chamber and a semicystic type of spermatogenesis for Black Anglerfish. This new information allows for a better understanding of Black Anglerfish reproduction-knowledge that will be useful for the assessment and management of this species.
\end{abstract}

Manuscript submitted 19 October 2012. Manuscript accepted 19 September 2013. Fish. Bull. 111:390-401 (2013).

doi: 10.7755/FB.111.4.8

The views and opinions expressed or implied in this article are those of the author (or authors) and do not necesarily reflect the position of the National Marine Fisheries Service, NOAA.

\title{
Reproductive biology of Black Anglerfish (Lophius budegassa) in the northwestern Mediterranean Sea
}

\author{
Ana I. Colmenero (contact author) \\ Víctor M. Tuset \\ Laura Recasens \\ Pilar Sánchez \\ Email address for contact author: colmenero@icm.csic.es \\ Institut de Ciències del Mar (ICM) \\ Consejo Superior de Investigaciones Científicas (CSIC) \\ Passeig Marítim de la Barceloneta 37-49 \\ 08003 Barcelona, Spain
}

Lophius, a genus commonly known as anglerfishes or monkfishes, includes 7 species broadly distributed and exploited worldwide. Most of these species inhabit the northwestern Atlantic, as do Goosefish (Lophius americanus) and Blackfin Goosefish ( $L$. gastrophysus), or the northeastern Atlantic, as do Cape Monk (L. vomerinus), Shortspine African Angler ( $L$. vaillanti), Black Anglerfish (L. budegassa), and White Anglerfish (L. piscatorius), although Black Anglerfish and White Anglerfish also live in the Mediterranean Sea and Yellow Goosefish (L. litulon) can be found only in the northwestern Pacific (Fariña et al., 2008). In the past, species of Lophius have been captured as bycatch in mixed fisheries, but an increase in their economic value, together with the overexploitation of other groundfish species, has led to the development of targeted anglerfish fisheries (Hislop et al., 2001). In the northwestern Mediterranean Sea, landings of Black Anglerfish and White Anglerfish have accumulated to just over 6000 metric tons during the last 10 years. ${ }^{1}$ The scarce reproductive information available for these species does not allow for a

1 Tudó Vila, P. 2012. Unpubl. data. Directorate of Fishing and Maritime Affaires, Government of Catalonia, Avinguda Diagonal, 523-525, 08029 Barcelona, Spain. proper assessment or informed management of anglerfish fisheries.

This study focuses on Black Anglerfish, a demersal fish distributed along the Mediterranean Sea, as well as the northeastern Atlantic from the British Isles to Senegal (Caruso, 1986). This species is found over the continental shelf and upper slope at depths of up to $800 \mathrm{~m}$ and inhabits sandy, muddy, and rocky bottoms (Carlucci et al., 2009). They occupy the water column as eggs and larvae, and then they shift to a benthic existence as juveniles and adults (Fariña et al., 2008). This species co-occurs with White Anglerfish over all its bathymetric range, although White Anglerfish has a deeper distribution that reaches to depths $>1000 \mathrm{~m}$ (Afonso-Dias and Hislop, 1996). Despite the overlapping distributions of these species, Colmenero et al. (2010) concluded that no ecological competition exists between these species because of a temporal segregation in their biorhythms; Black Anglerfish is more active at nighttime, and White Anglerfish is more active during daytime.

Most studies of these species have been undertaken in northeastern Atlantic waters, and they often have dealt with age and growth (Dupouy et al., 1984; Landa et al. 2008a; Woodroffe et al., 2003), feeding habits (Crozier, 1985; Laurenson 


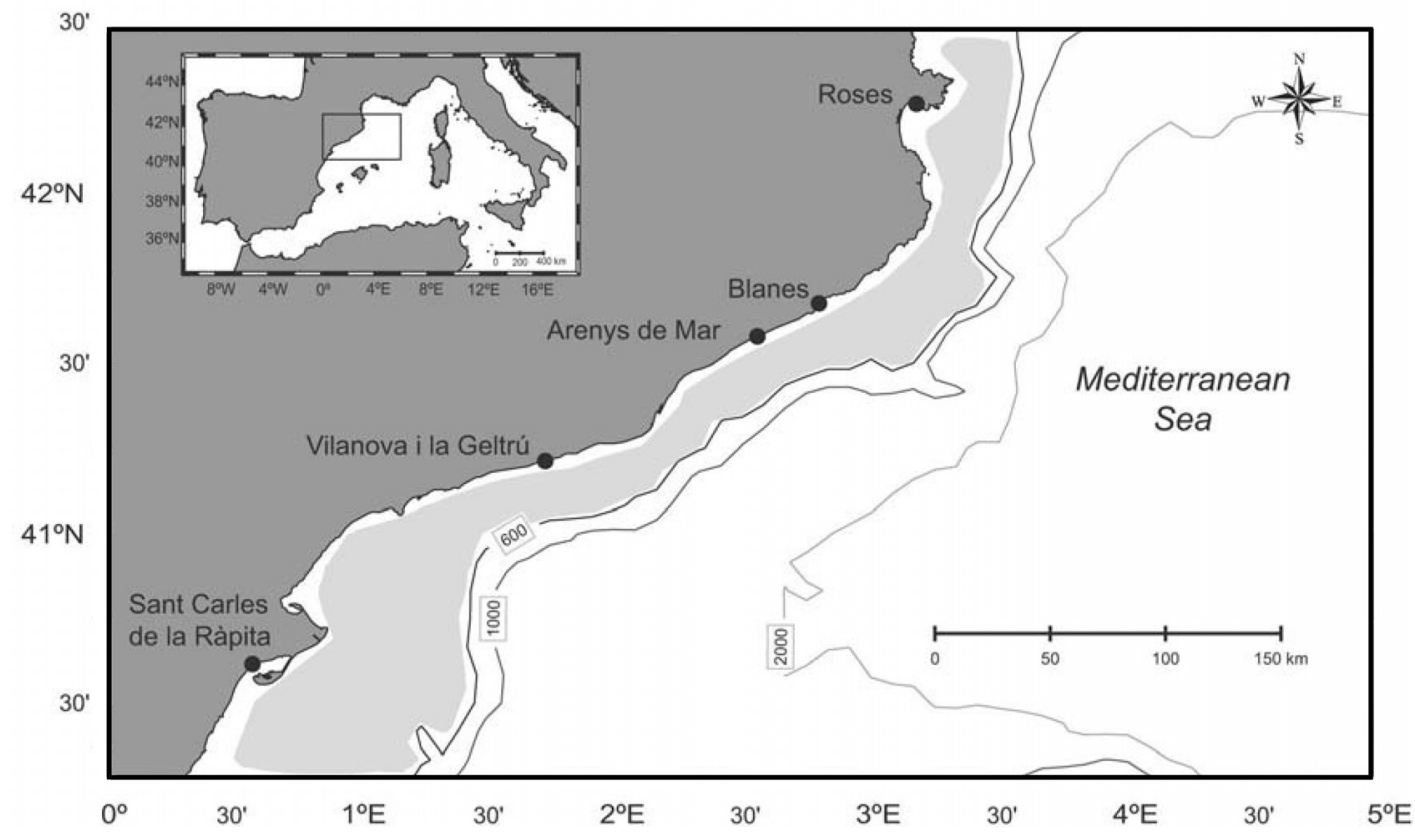

Figure 1

Map of study area where specimens of Black Anglerfish (Lophius budegassa) were collected in the northwestern Mediterranean Sea between June 2007 and December 2010 to examine the reproductive biology of this species. The zone shaded in light gray closest to the Catalan coast indicates the sampling area. The cities shown on the coast were the ports of commercial trawl fishery vessels from which specimens were collected.

and Priede, 2005; Preciado et al., 2006), geographical and depth distribution (Caruso, 1985; Landa et al., 2008b; Velasco et al., 2008), and reproduction (AfonsoDias and Hislop, 1996; Duarte et al., 2001; Laurenson, 2006). In the Mediterranean Sea, studies have been less numerous and for the most part have focused on biological aspects similar to the ones examined in the studies just described (Carlucci et al., 2009; Colmenero et al., 2010; García-Rodríguez et al., 2005; La Mesa and De Rossi, 2008; Maravelias and Papaconstantinou, 2003; Negzaoui-Garali and Ben Salem, 2008; NegzaouiGarali et al., 2008; Tsimenidis, 1984; Tsimenidis and Ondrias, 1980; Ungaro et al., 2002). However, only Tsimenidis (1980) and Carbonara et al. (2005) focused on reproductive traits of Black Anglerfish.

Information about the duration of the spawning season, fish size at first maturity, reproductive strategy, maturation of oocytes, and fecundity are very relevant for studies of the biology and population dynamics used in stock assessments for management of fishery resources. Of all these reproductive features, fecundity is the most difficult biological parameter to obtain, although it is critical for accurate stock assessments (Trippel et al., 1997). In the peculiar case of species of Lophius, studies on fecundity are scarce because of the difficulty of 1) acquisition of suitably mature individuals in the maturity phases of spawning capable or actively spawning and 2) the use of a proper method for fecundity estimation, which is especially complicated because of the morphological features of the gonads of these species. During reproduction, a gelatinous material is secreted into the lumen, and enumeration and measurement of eggs embedded in this mucus matrix is extremely difficult.

Although species of Lophius have similar traits throughout the world, some biological aspects and catch trends of fisheries present interspecific and spatial variations (Fariña et al., 2008). For that reason, reproductive parameters of the Atlantic stock of Black Anglerfish cannot be applied to the stock in the Mediterranean. In addition, knowledge of the reproductive biology of this species in the northwestern Mediterranean Sea is very limited. Therefore, our study is the first one to take a detailed approach to the examination of reproductive traits of Black Anglerfish in the Mediterranean Sea, and the results of this study can contribute to improvement of stock assessment and effective management of this species in this region.

\section{Materials and methods}

\section{Sample collection}

Monthly samples of Black Anglerfish were obtained from 467 sampling stations situated in the fishing grounds off the Catalan coast in the northwestern Mediterranean Sea from $40^{\circ} 5.980^{\prime} \mathrm{N}$ to $43^{\circ} 39.310^{\prime} \mathrm{N}$ 


\section{Table 1}

Macroscopic and microscopic description of the 5 maturity phases in the reproductive cycle of male and female Black Anglerfish (Lophius budegassa) collected from the northwestern Mediterranean Sea between June 2007 and December 2010; adapted from Afonso-Dias and Hislop (1996) and Brown-Peterson et al. (2011).

\begin{tabular}{lll}
\hline Phase & Males & Females
\end{tabular}

Immature (I)

Developing/

Regenerating (II)

Spawning capable (III)

Actively spawning (IV)

Regressing (V)
Testes are long, narrow, and tubular shaped. They are translucent with no visible vascularization. The medial seminiferous duct is distinct. Only spermatogonia and primary spermatocytes are present.

Testes are small with visible blood vessels around the seminal duct. Spermatogonias, primary and secondary spermatocytes are predominant. Spermatids are scarce.

Testes increase in length and width. They have a firm texture and cream color. Seminal duct is highly vascularized. Germ cells at all stages of spermatogenesis are present. Spermatids are predominant with a lot of spermatozoa in the lumen of the sperm duct.

Testes are large and firm and have a creamy coloration. Large amounts of sperm produced when testes are dissected. Abundant quantities of spermatozoa are present in the seminiferous tubules.

Testes are small, flaccid, and have brown or red areas in their beige surface. They are still highly vascularized. Sperm and residual spermatozoa can be found in the lumina of the sperm duct. Spermatogonia are present in the testes cortex.
Ovaries are very narrow, thin, and flattened-tube shaped. They are translucent; no oocyte clusters visible and minimal vascularization. Only oogonia and primary growth oocytes are present.

Ovaries are small. Still no noticeable individual oocyte clusters. They acquire a cream color and vascularization is visible. Only oogonia and primary growth oocytes are present.

Ovaries increase in width and length. They have a light orange color, and blood vessels are prominent. The edges of the ovaries start to curl and they occupy a larger proportion of the body cavity. A mucus matrix starts to develop. Primary growth, cortical alveolar, and primary and secondary vitellogenic oocytes are present.

Ovaries are extremely long and wide and occupy most of the body cavity. The color of the oocytes is orange, and they are visible macroscopically. Ovaries are characterized by the presence of large hyaline oocyte clusters enclosed in a transparent gelatinous matrix that is completely developed. High vascularization is present. Oocytes are in tertiary vitellogenesis, migratory nucleus and hydration.

Ovaries are flaccid and highly vascularized and often have longitudinal striations. Their color is dark pink or red. Atresia and postovulatory follicles, together with primary growth stages, are present. Cortical alveolar, primary and secondary vitellogenesis can be found. and from $0^{\circ} 32.922^{\prime} \mathrm{E}$ to $3^{\circ} 35.718^{\prime} \mathrm{E}$ between June 2007 and December 2010. Specimens were collected onboard commercial trawl fishery vessels at depths of 20-600 $\mathrm{m}$ and identified according to Caruso (1986). The trawl fleet belonged to the ports of Roses, Blanes, Arenys de Mar, Vilanova i la Geltrú, and Sant Carles de la Ràpita (Fig. 1). For this study, 4410 specimens were measured to the nearest centimeter in total length (TL), weighed to the nearest gram in total weight (TW) and gutted weight (GW), and measured with an accuracy of $0.01 \mathrm{~g}$ in gonad weight (GNW) and liver weight (LW).

\section{Macroscopic and histological description of gonads}

Of the total number of specimens, 3562 fish had gonads removed and their sex was determined, and they were assigned macroscopically to a gonadal stage on the basis of a scale with 5 maturity phases that were described in previous studies: immature (phase I), developing or regenerating (phase II), spawning capable (phase III), actively spawning (phase IV), and regressing (phase V) (Afonso-Dias and Hislop, 1996; Brown-Peterson et al., 2011) (Table 1). Sex was easily assessed macroscopically in mature individuals. However, gonads from small individuals (approximately $<20 \mathrm{~cm}$ TL) were indistinguishable macroscopically because ovaries and testes were small, translucent, and string-like. Fish that were too small to determine their sex or assign to a gonadal phase were classified as indeterminate.

To corroborate the macroscopic classification of some unclear and undetermined gonads, 372 specimens were histologically examined. They were fixed in $10 \%$ buffered formalin solution before they were dehydrated and embedded in a methacrylate polymer resin. 
Cross sections, each 3-4 $\mu \mathrm{m}$ thick, were made with a manual microtome Leica Reichert-Jung 2040 (Leica Microsystems, ${ }^{2}$ Wetzlar, Germany), stained with Lee's stain (methylene blue and basic fuchsin), and mounted in a synthetic resin of dibutyl phthalate xylene (DPX) on microscope slides. Gonads were classified according to the morphological features and the presence of specific inclusions (oil droplets, yolk granules, yolk vesicles, or postovulatory follicles) (Wallace and Selman, 1981). The ovarian and testicular phases were defined by the developmental stage of the most advanced cell within the gonad (Yoneda et al., 1998b).

\section{Spawning season and size at first maturity}

The spawning season was established from the analysis of the monthly variation of the maturity phases and the changes in gonadosomatic (GSI) and hepatosomatic (HSI) indices for each sex (Afonso-Dias and Hislop, 1996). Because immature specimens were not considered, 1437 males and 1167 females were used to determine both indices, which were calculated according to Yoneda et al. (2001) with the following equations:

$$
\begin{gathered}
G S I=(G N W / G W) \times 100 . \\
H S I=(L W / G W) \times 100 .
\end{gathered}
$$

Size at first maturity $\left(L_{50}\right)$ was determined through the examination of males and females in mature phases (phase III, phase IV, or phase V) and immature individuals collected during the spawning period (Duarte et al., 2001). Total length of all individuals was used to estimate $L_{50}$, defined as the size at which $50 \%$ of all fish sampled were at sexually mature phases. Maturity curves were determined with a logistic curve (Pope et al., 1975):

$$
P=100 /(1+\exp [a+b \mathrm{TL}]),
$$

where $P=$ the percentage of mature individuals as a function of size class (TL); and

$a$ and $b=$ specific parameters that can change during the life cycle.

A logarithmic transformation was applied to this equation to calculate the parameters $a$ and $b$ by means of linear regression.

\section{Reproductive strategy and fecundity}

Patterns of ovarian organization and fecundity were tested by oocyte size-frequency distributions (West, 1990). For our analysis, 36 fish, with lengths between 20.0 and $72.5 \mathrm{~cm}$ TL, were randomly selected from all maturity phases. From these fish, 4428 oocyteswith more than 300 oocytes from each maturity phase (I=961; II=1106; III=1046; IV=381; V=934)—were mea-

\footnotetext{
${ }^{2}$ Mention of trade names or commercial companies is for identification purposes only and does not imply endorsement by the National Marine Fisheries Service, NOAA.
}

sured for their diameter with an image analysis program (Image-Pro Plus, vers. 5.0, Media Cybernetics, Inc., Rockville, MD) in combination with an Axioskop 2 Plus microscope (Carl Zeiss Microscopy, LLC, Thornwood, NY) and a ProgRes C14 digital microscope camera (Jenoptik AG, Jena, Germany). Diameters were measured to the nearest $0.01 \mu \mathrm{m}$. The mean oocyte diameter by developmental stage was determined by calculating the diameter of all oocytes encountered in each subsample. Measurements were taken only of oocytes that were sectioned through the nucleus (AfonsoDias and Hislop, 1996).

Before fecundity was estimated, the gonads of 7 individuals were divided into 3 sections (anterior, middle, and posterior) to test differences in mean oocyte density within the ovary by using a one-way analysis of variance (ANOVA). This use of 3 sections ensured that the analyzed subsample represented the entire ovary (Murua et al., 2003). Batch fecundity (BF), the total number of mature eggs produced in a single spawning batch by an individual female, was estimated by using the gravimetric method on the basis of the relation between ovary weight and the density of oocytes in the ovary (Hunter and Goldberg, 1980). Three ovarian tissue samples of known weight, representing $10 \%$ of the total ovarian weight, were extracted from different areas of the same ovary (anterior, middle, and posterior ovarian lobe). These subsamples were collected from 15 specimens with ovaries in phases III and IV with neither postovulatory follicles nor atretic oocytes present. Because the oocytes could not be extracted from their mucogelatinous matrix without destroying them, whole tissue subsamples were mounted on several slides for analysis and covered with a cover slip.

Images of each ovarian tissue sample were taken with a Canon Powershot SD870 IS digital camera (Canon USA, Melville, NY), and oocytes were counted manually with Image-Pro Plus software. Fecundity values were obtained by examining Black Anglerfish with total lengths of 46-65 cm, TW of 1096-5592 g, GW of 986-3600 g, and GNW of 88.70-2300 g. Batch fecundity for each female was calculated as a product of the number of secondary vitellogenic oocytes per unit of weight multiplied by the total ovarian weight (Yoneda et al., 2001). Relative batch fecundity (RBF), the total number of mature eggs released by a female during the spawning batch per gram of body weight of gutted fish, was calculated as BF divided by GW (Pavlov et al., 2009):

$$
\begin{gathered}
B F=(\text { oocyte } \\
\times \text { number } / \text { sampled GNW }) \\
R B F=B F / G W .
\end{gathered}
$$

Linear regression analysis was used to examine the relationships between $\mathrm{BF}$ and fish TL, TW, and GW (Armstrong et al., 1992). Linear regression analysis also was applied to analyze the relationship between RBF and TL. Mean potential fecundity was 


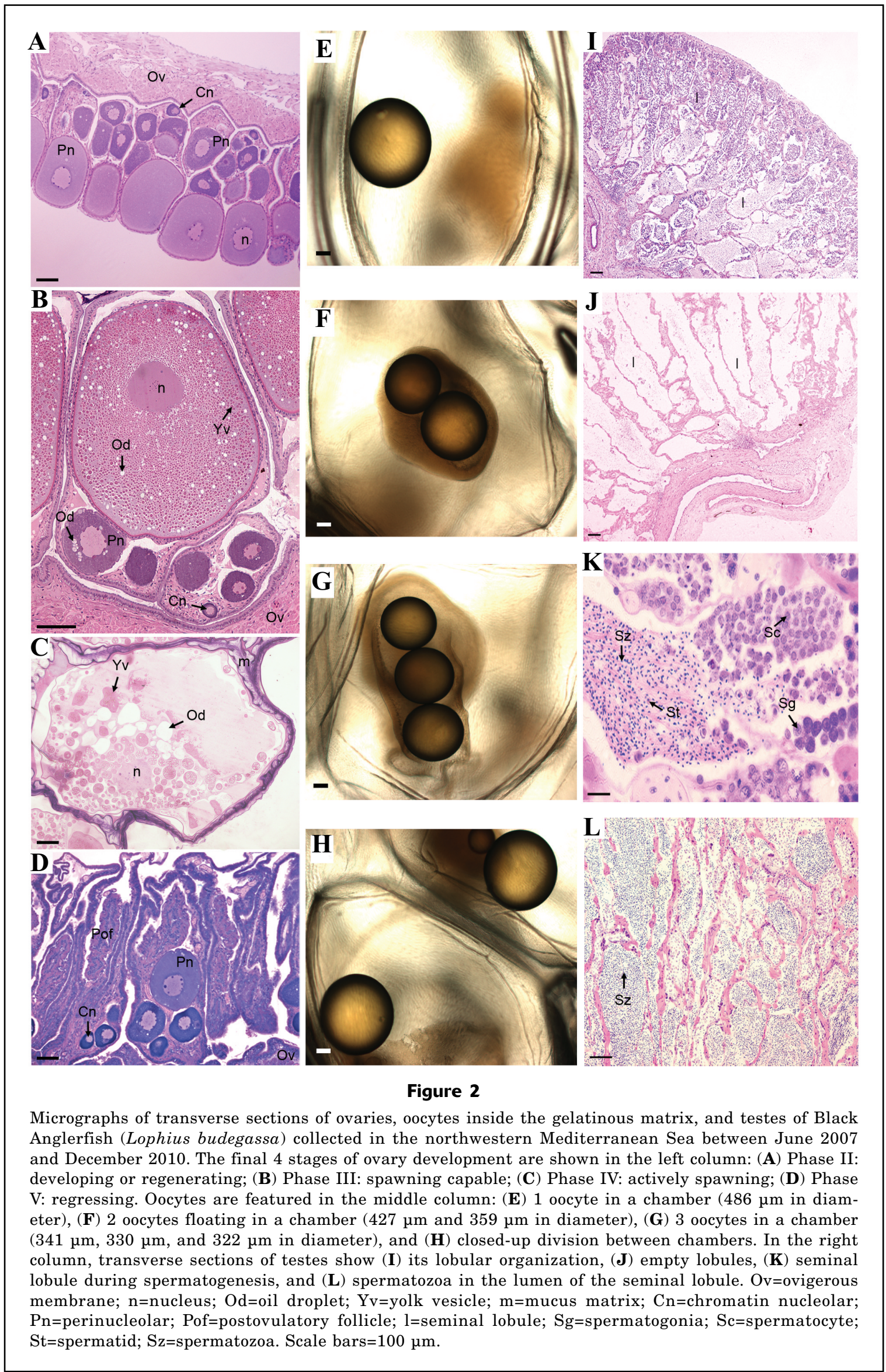


also calculated as the number of vitellogenic oocytes divided by kilogram of mature female (Murua et al., 2003).

\section{Results \\ Gonadal morphology}

Ovarian structure consists of a flattened band with 2 distinctive lobes that are folded up and connected to each other at their posterior end. The lobes form a single organ attached to the abdominal cavity by a black mesenteric tissue called the mesovarium. One side of the ovarian wall is made of an ovigerous membrane and connective tissue. The nonovigerous side is made of epithelial cells. A single layer of oocyte clusters projects from the ovigerous membrane to the lumen (Fig. 2A). Inside each gonad, the clusters can be in different development stages. Only the oocytes situated closest to the tip of the clusters have progressed through all maturity stages, and the other oocytes are only oogonia or in the primary growth stage (Fig. 2B).

A gelatinous material is secreted into the lumen during the late phases of gonad maturation, producing the mucus matrix characteristic of the reproduction of Lophius species (Fig. 2C). Hydration of the oocytes occurs just before spawning, and postovulatory follicles (Fig. 2D) are found during the regression phase of the reproductive cycle. Ripe eggs, which are usually situated on the tip of the oocyte cluster, rupture the follicles and are pressed into the layer of mucus. In this study, every chamber examined contained at least 1 egg in the gelatinous matrix (Fig. 2E), although the presence of 2 (Fig. $2 \mathrm{~F}$ ) or 3 eggs (Fig. $2 \mathrm{G}$ ) floating in separate chambers was also noted (Fig. $2 \mathrm{H}$ ).

Oocyte diameter appeared to differ depending on the quantity of oocytes present in each chamber; the oocytes that were isolated in their chambers were found to be larger in size than other oocytes. A diameter of $486 \mu \mathrm{m}$ was obtained for the oocyte that was the single oocyte in its chamber. Diameters of $427 \mu \mathrm{m}$ and 359 $\mu \mathrm{m}$ were found for the 2 oocytes floating together in a chamber, and diameters of $341 \mu \mathrm{m}, 330 \mu \mathrm{m}$, and 322 $\mu \mathrm{m}$ were observed for the 3 oocytes that shared the same chamber. Measurements of more oocyte diameters are needed to confirm these preliminary observations.

The testes are a pair of elongated and tubular structures located in the dorsal portion of the abdominal cavity, and they are bean-shaped in transverse section. The organization of the testes is lobular: the connective tissue extends from the testicular capsule to form lobules that have their blind ends on the surface of the gonads, converging ventrally towards the sperm duct (Fig. 2I). These lobules are fused to the posterior end of each testicular lobe to form a common sperm duct that leads to a genital pore (Fig. 2J). Spermatogenesis takes place in a capsule-like sac called a cyst, but it is not completed within the cyst. Each cyst contains spermatogonia or developing spermatocytes (Fig. 2K). Before the end of the spermatogenesis, the cyst breaks up and spermatids are released into the lumina of the lobules, where spermatogenesis is then completed and spermatids transform into spermatozoa (Fig. 2L). The cysts appear to be arranged in order of maturation, with a gradient of germ cells of increasing maturation from the cortex to the sperm duct. The shape of the spermatozoa head seems to be elongated.

\section{Spawning season and size at first maturity}

Monthly distribution of macroscopic classification of the maturity phases (Fig. 3, A and B) revealed that the period of maximum occurrence of females in the spawning capable phase (III) was from November to January. The presence of females in the actively spawning phase (IV) was observed from November to March, with a maximum peak in January. Females in the immature, regressing, and developing and regenerating phases (I, $\mathrm{V}$, and II, respectively) were found throughout the year, with the highest percentage of immature individuals seen in May. A slight increase in phase-III females was observed in August, and that increase would likely result in spawning activity in September, indicating the possibility of a secondary breeding season. Males in all maturity phases were observed throughout the year, with 2 maxima of mature males occurring in December and July.

For mature males and females, GSI and HSI indices were calculated. In males, GSI was fairly constant throughout the year and a maximum index value of 1.06 was reached in January (Fig. 3C). The mean GSI for females was highest from December to March, with a peak of maximum activity in January (4.94) and February (2.43) (Fig. 3D). The mean HSI for females and males followed the same pattern. The highest value for males was found in September (2.50), and the lowest value in February (1.65) (Fig. 3C). In females, HSI values ranged from 3.19 in January to 1.86 in March (Fig. $3 \mathrm{D})$. The highest HSI values were found just at the beginning of the main spawning season. GSI and HSI results, together with observations of maturity phases throughout the year, indicate that there is one main spawning season from November to March.

Comparison of $L_{50}$ curves showed a clear difference between males and females. The size at $50 \%$ sexual maturity was $33.4 \mathrm{~cm}$ TL for males (Fig. 4A) and 48.2 cm TL for females (Fig. 4B).

\section{Reproductive strategy and fecundity}

The size-frequency distributions of oocyte diameters in each of the 5 maturity phases indicate that oocytes in different stages of development were found in each maturity phase (Table 2; Fig. 5). During phase I, only oocytes in the primary growth stage (chromatin nucleolar and perinucleolar) with a narrow range of diameters were present (Fig. 5A). In phase II, cortical alveolar 


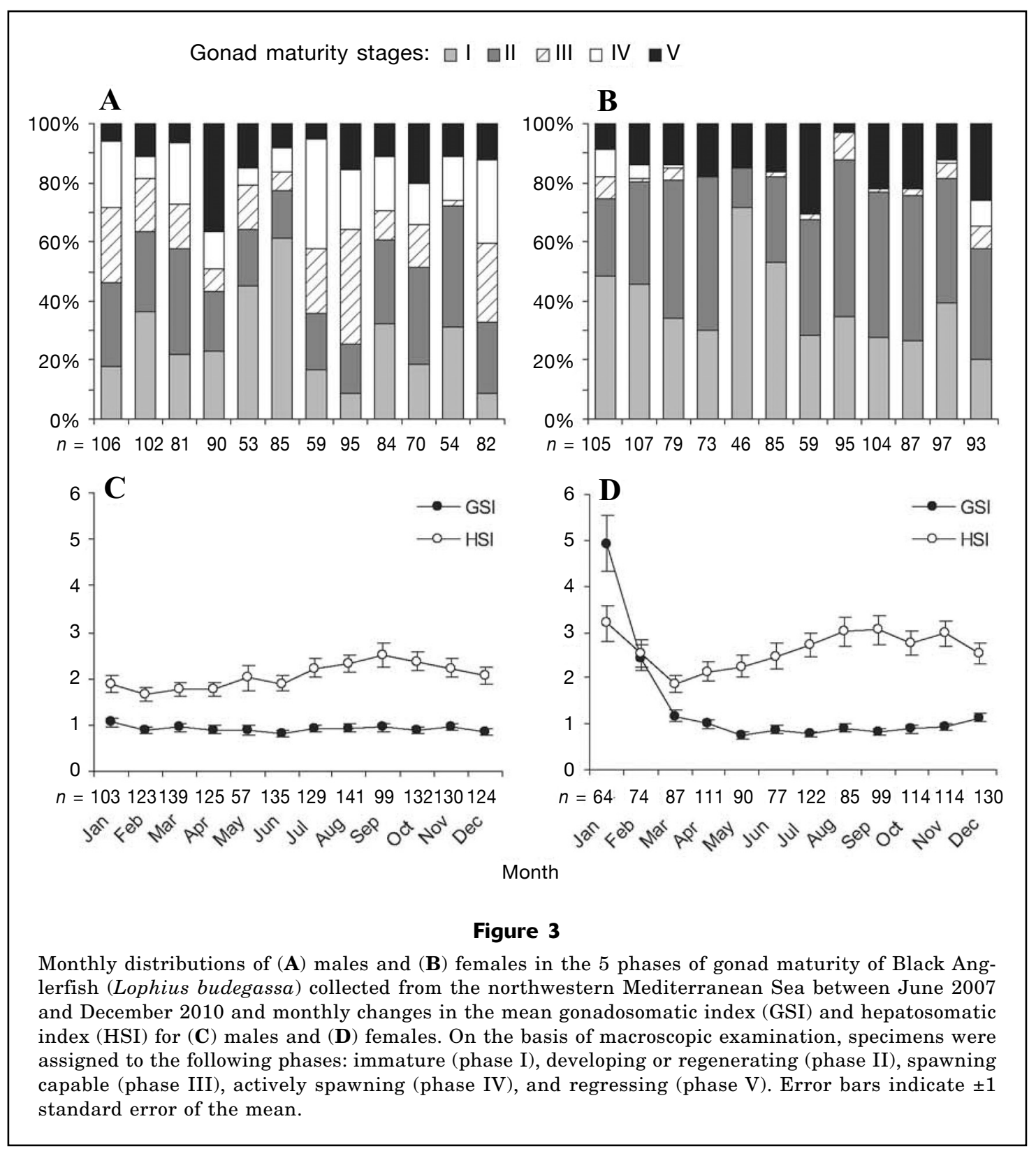

vesicles were found in the cytoplasm together with oocytes in the stage of primary growth with diameters that had increased notably (Fig. 5B). In phase III, yolk granule stages (Murua et al., 2003) were present along with the previous 2 types of oocytes. The oocytes increased in size as the yolk accumulated, and a wider oocyte diameter range distribution was observed during this phase (Fig. 5C). In phase IV, oocytes were observed in different stages (primary growth, vitellogenesis, migratory nucleus, and hydration). Two populations of oocytes were recognized in phase IV: a population of larger oocytes (defined as a clutch) and a population of smaller oocytes from which the clutch was recruited (Fig. 5D). In phase $\mathrm{V}$, oocytes in the primary growth stage were found along with postovulatory follicles and atretic oocytes (Fig. 5E).

The presence of oocytes in different developmental stages within the same cluster and the frequency distribution of oocyte diameter along all maturity phases indicate that oocyte development in Black Anglerfish is group-synchronous. The existence of a gap that separates the yolked oocyte stock, the ones to be spawned during the current breeding season, from the unyolked oocytes, the ones to be spawned in the coming breeding season, together with the increase of the mean diameter of the advanced vitellogenic oocytes, indicates that annual fecundity is determinate.

Significant differences in oocyte densities among 


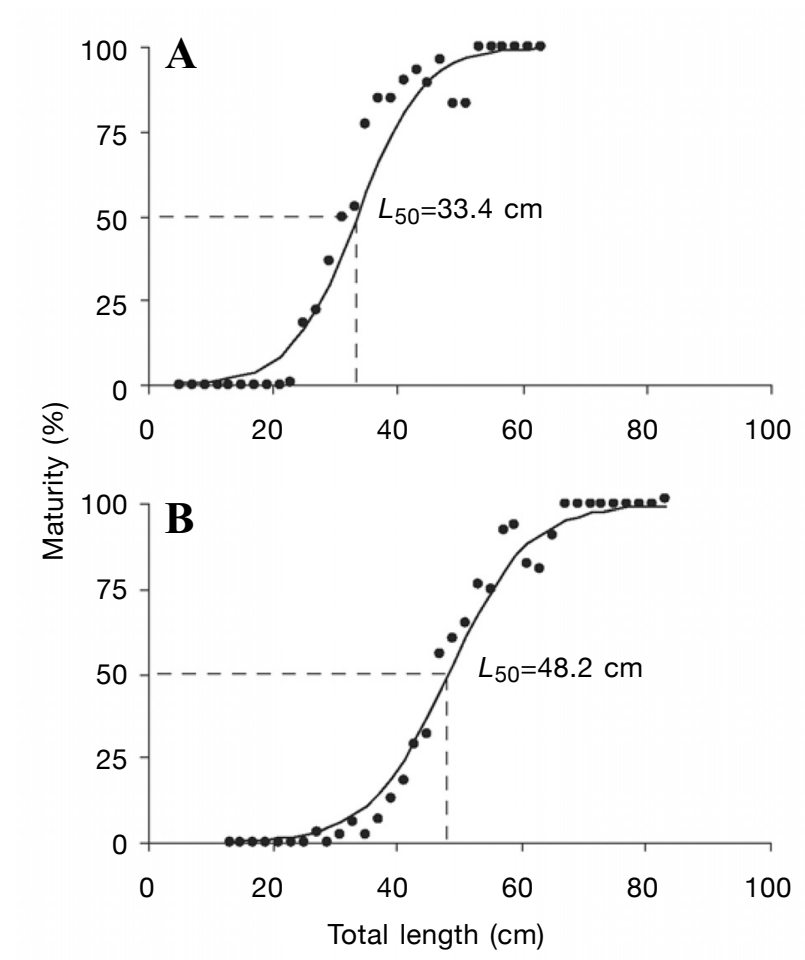

Figure 4

Maturity ogives used to estimate length at maturity $\left(L_{50}\right)$ for $(\mathbf{A})$ male and (B) female Black Anglerfish (Lophius budegassa) collected from the northwestern Mediterranean Sea between June 2007 and December 2010.

ovary sections were not observed (ANOVA, $\mathrm{F}_{(2,42)}=0.002$, $P=0.998$ ). Batch fecundity ranged between 87,569 and 398,986 oocytes, and mean BF was 218,020 oocytes (standard error of the mean [SE] 90,018). Relative batch fecundity was estimated at 102 (SE 20) oocytes per gram of female (GW), and mean potential fecundity was 78,929 (SE 13,648) oocytes per kilogram of mature female.

Batch fecundity tended to increase linearly with TL (linear regression, coefficient of determination $\left[r^{2}\right]=0.89, F_{1,13}=106.57, P<0.001$ ), TW (linear regression, $r^{2}=0.82, F_{1,13}=60.79, P<0.001$ ), and GW (linear regression, $\left.r^{2}=0.82, F_{1,13}=59.31, P<0.001\right)$, indicating that fecundity is dependent on size and body weight (Fig. 6). No significant correlation was found between $\mathrm{RBF}$ and $\mathrm{TL}$, indicating that RBF is not size dependent (linear regression, $\left.r^{2}=0.16, F_{1,13}=2.50, P=0.138\right)$.

\section{Discussion}

This study indicates that oocyte development and the fecundity pattern of Black Anglerfish are similar to findings for other species of Lophius: White Angler-

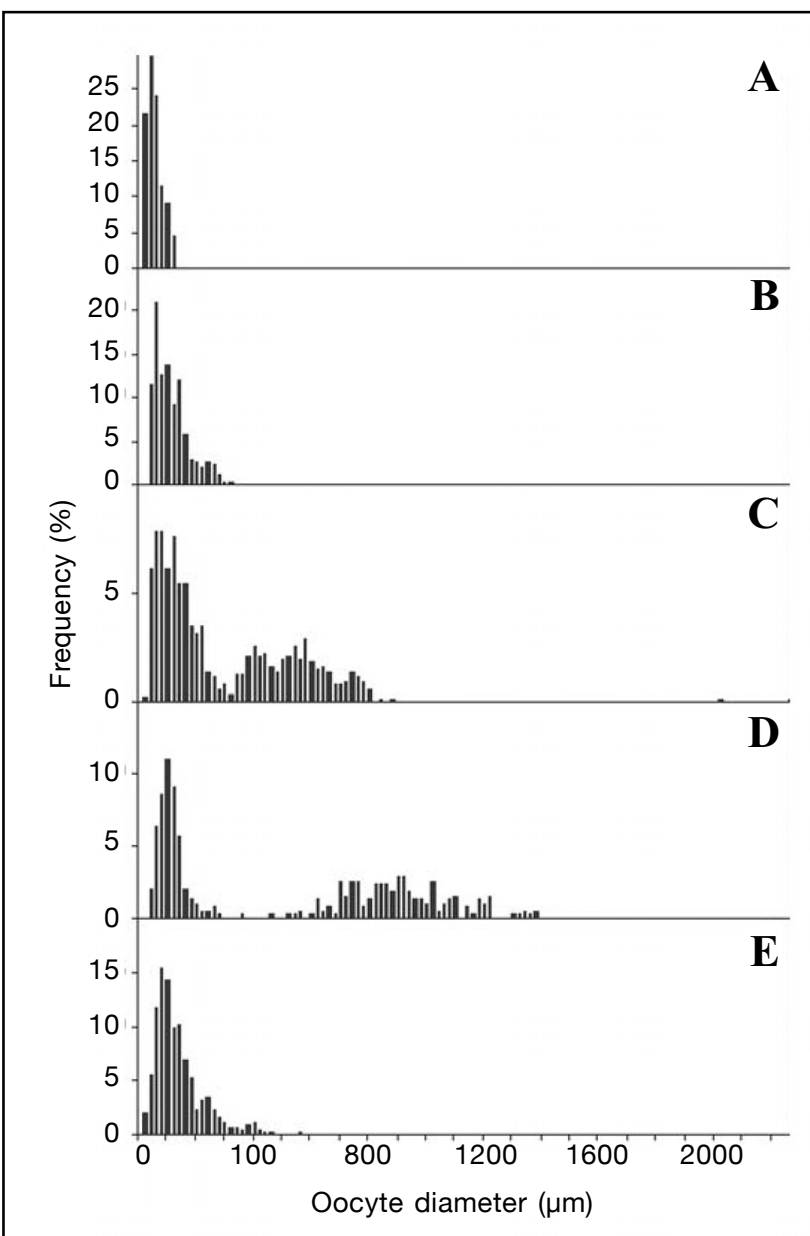

Figure 5

Size-frequency distributions of oocyte diameters at each phase of gonad maturity of Black Anglerfish (Lophius budegassa) collected from the northwestern Mediterranean Sea between June 2007 and December 2010. The 5 maturity phases are (A) phase I, immature, $n=961$; (B) phase II, developing or regenerating, $n=1106$; (C) phase III, spawning capable, $n=1046$; (D) phase IV, actively spawning, $n=381$; (E) phase V, regressing, $n=934$.

fish (e.g., Fulton, 1898), Cape Monk (Leslie and Grant, 1990), Goosefish (Armstrong et al., 1992) and Yellow Goosefish (Yoneda et al., 2001). The eggs of Black Anglerfish appear to be shed as a part of a single event and are likely released only once during the spawning season-the pattern of a total spawner. This type of spawning has been observed also in Goosefish (e.g., Feinberg, 1984) and White Anglerfish (Afonso-Dias and Hislop, 1996), although the possibility of spawning several batches over the spawning season is not unfeasible because this behavior has been described for Yellow Goosefish (Yoneda et al., 2001).

Batch fecundity estimates for Black Anglerfish reveal a positive relationship between number of oocytes 


\section{Table 2}

Oocyte histological characteristics of Black Anglerfish (Lophius budegassa) collected between June 2007 and December 2010 in the northwestern Mediterranean Sea; descriptions follow those of Wallace and Selman (1981). Mean oocyte diameters, which were measured to the nearest $0.01 \mu \mathrm{m}$, are provided by developmental stage with standard errors of the mean (SE).

\begin{tabular}{|c|c|c|}
\hline $\begin{array}{l}\text { Oocyte developmental } \\
\text { stage }\end{array}$ & $\begin{array}{c}\text { Oocyte } \\
\text { diameter }(\mu \mathrm{m})\end{array}$ & Histological characteristics \\
\hline Chromatin nucleolar & $36.55(\mathrm{SE} 21.27)$ & $\begin{array}{l}\text { Nucleus contains a large nucleolus and some small peripheral nu- } \\
\text { cleoli. Yolk granules are not present in the cytoplasm. }\end{array}$ \\
\hline Perinucleolar & $110.78(\mathrm{SE} 62.54)$ & $\begin{array}{l}\text { Nucleus grows and several big peripheral nucleoli and vacuoles are } \\
\text { present. No yolk granules are present in the cytoplasm. }\end{array}$ \\
\hline Cortical alveolar & $256.35(\mathrm{SE} 80.81)$ & $\begin{array}{l}\text { Nucleus is central. Cortical alveolar vesicles and oil droplets ap- } \\
\text { pear in the cytoplasm. Yolk granules are still not present in the } \\
\text { cytoplasm. }\end{array}$ \\
\hline Primary vitellogenic & $364.54(\mathrm{SE} 37.31)$ & $\begin{array}{l}\text { Yolk granules appear between cortical alveolar vesicles. Nucleus } \\
\text { remains central. }\end{array}$ \\
\hline Secondary vitellogenic & $406.20(\mathrm{SE} 39.60)$ & Yolk granules fill the cytoplasm. Nucleus is still central. \\
\hline Tertiary vitellogenic & $544.55(\mathrm{SE} 185.49)$ & $\begin{array}{l}\text { Yolk granules are in contact with the nucleus, which is still central, } \\
\text { and the oocyte size has increased from size at previous stages. }\end{array}$ \\
\hline Migratory nucleus & $883.42(\mathrm{SE} 153.33)$ & $\begin{array}{l}\text { Yolk granules and oil droplets start to fuse. Nucleus migrates to one } \\
\text { pole of the oocyte. }\end{array}$ \\
\hline Hydration & $1125.09(\mathrm{SE} 176.93)$ & $\begin{array}{l}\text { Yolk granules form a single mass. Nucleus is not present in the } \\
\text { cytoplasm. }\end{array}$ \\
\hline
\end{tabular}

and fish length and weight; therefore, large spawners have a higher contribution to egg production than do smaller ones. Previous authors have found lower fecundity values than the ones observed in this study. In the Tyrrhenian Sea, Carbonara et al. (2005) determined mean potential fecundity as 54,057 oocytes per kilogram of mature female and total fecundity as 211,687 oocytes from data obtained from a single individual (59 cm TL). In the case of the Aegean Sea, where fecundity values varied from 105,800 to 284,200 oocytes, fecundity was determined from an undefined number of individuals and size range (Tsimenidis, 1980).

Another relevant feature of the reproduction of Black Anglerfish is the presence of a gelatinous matrix, which has been noted for other Lophius species (Armstrong et al., 1992; Fulton, 1898; Leslie and Grant, 1990; Yoneda et al., 2001). The matrix consists of individual chambers where hydrated oocytes are released. In our study, we detected the presence of 2 or 3 eggs in some chambers (Fig. 2). This phenomenon also has been described for Goosefish, and it has been assumed that such eggs in that species may have been fertilized (Armstrong et al., 1992; Everly, 2002). Trippel et al. (1997) concluded that for the same species, larger eggs have a higher probability of hatching and of subsequent larval survival than do smaller ones. It is unknown whether the smaller eggs of Black Anglerfish that share a chamber hatch at a different rate or produce less viable larvae than the larger eggs that are alone in a chamber.
Finally, the semicystic kind of spermatogenesis has been described only once before in the family Lophiidae, for Blackmouth Angler (Lophiomus setigerus) (Yoneda et al., 1998a). Muñoz et al. (2002) reported that semicystic spermatogenesis may be related to the secretion of abundant, thick seminal fluid, the function of which is to keep the spermatozoa together to enable fertilization of the entire egg mass.

The variation in spawning seasonality of Black Anglerfish between spring (La Mesa and De Rossi, 2008) and winter (Carbonara et al., 2005; Duarte et al., 2001; Tsimenidis, 1980) may be associated with local oceanographic features. Eddies and fronts enhance productivity, often function as physical barriers that retain larvae and juveniles, and provide favorable conditions for the feeding behavior of recruits and their subsequent transport toward the main nursery areas (Sánchez and Gil, 2000). During spring and summer, temporary eddies are generated in the Adriatic Sea (Mediterranean Sea) and in the Bay of Biscay (Atlantic) (Artegiani et al., 1997a, 1997b). In contrast, in wintertime eddies are generated in the Aegean and the Tyrrhenian seas, and the northern component of the outflow water from the Mediterranean Sea influences the Atlantic Iberian coast (Iorga and Lozier, 1999).

Finally, maturity sizes between individuals off the Atlantic Iberian coast, $53.6 \mathrm{~cm}$ TL in females and 38.6 cm TL in males (Duarte et al., 2001), and individuals in the northwestern Mediterranean Sea, $48.2 \mathrm{~cm}$ TL 

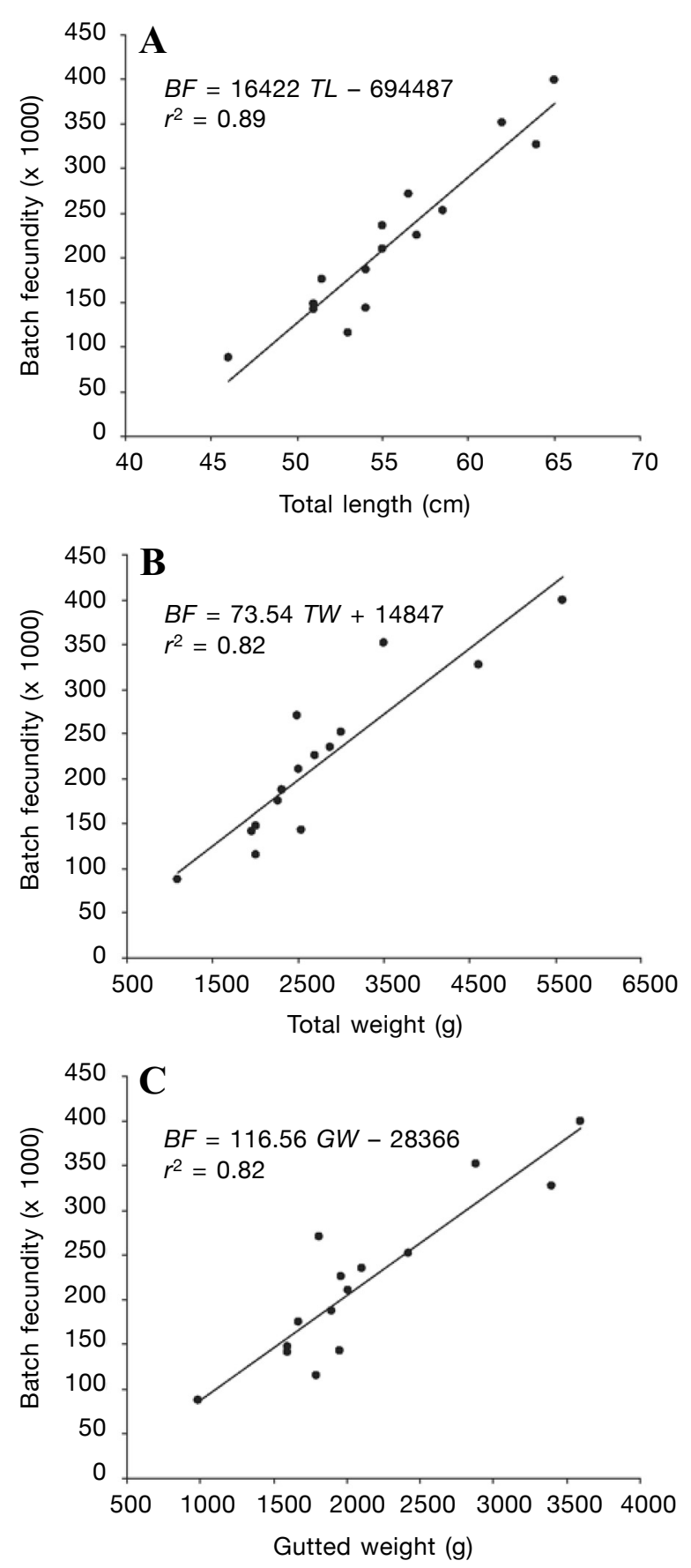

Figure 6

Relationships between batch fecundity (BF) and (A) total length (TL), (B) total weight (TW), and (C) gutted weight (GW) for Black Anglerfish (Lophius budegassa) collected from the northwestern Mediterranean Sea between June 2007 and December 2010. $r^{2}=$ coefficient of determination. in females and $33.4 \mathrm{~cm}$ TL in males in our study, were very similar, in contrast to the sizes observed for individuals in the Aegean Sea, $34 \mathrm{~cm}$ TL in females and 24 $\mathrm{cm}$ TL in males (Tsimenidis, 1980). These variations in $L_{50}$ could be related to environmental and anthropogenic factors (e.g., temperature, food availability, or fishing pressure) (Trippel et al., 1997).

\section{Conclusions}

Black Anglerfish is a bycatch species in commercial fisheries off the Catalan coast of Spain. Despite not being a target species for these fisheries, the rise of its economic value has led to an increase of captures in the northwestern Mediterranean Sea. The lack of information about reproduction and fecundity of the Black Anglerfish off the Catalan coast has been a problem for management of the fishery for Black Anglerfish. The results of our study improve the current understanding of the reproductive dynamics of this species. From the morphological point of view, the structure and the development of ovaries and testes do not differ from the development of gonads in other Lophiiformes, although Black Anglerfish presents variation in its spawning season-a variation that is linked to its geographic area.

Our most important results are for $L_{50}$. Males and females both reach $L_{50}$ at large sizes: $33.4 \mathrm{~cm}$ TL for males and $48.2 \mathrm{~cm}$ TL for females. As a consequence, the large catch and retention of individuals below the $L_{50}, 57 \%$ of males and $83 \%$ of females landed, indicate that overfishing of this species could be a concern in the northwestern Mediterranean Sea. Therefore, our study provides new data that are needed for a better understanding of the biology and ecology of Black Anglerfish; this knowledge will be useful in assessment and management of the stock that is exploited by the fisheries of the northwestern Mediterranean Sea.

\section{Acknowledgments}

We thank the crews of the fishing vessels Avi Pau, Estel. lada, Germans Félix, San Benito, and Port de Roses for their collaboration during sampling. We also recognize M. Baeta and L. Martínez for their help with data collection; S. Torres, R. Sánchez, and I. Salvo for their assistance with histological and fecundity analyses; and A. Ospina for development of the study area map. We appreciate M. Casadevall and M. Muñoz for their valuable comments about male reproduction. Special thanks go to C. Vestfals for editorial help. This study was conducted within the project, Monitoratge dels recursos pesquers i marisquers al litoral català (Direcció General de Pesca i Afers Marítims, Generalitat de Catalunya). V. Tuset is a scientist of CSIC within the modality JAE-Postdoc of Programme Junta para la Ampliación de Estudios cofunded by the European Social Foundation. 


\section{Literature cited}

Afonso-Dias, I. P., and J. R. G. Hislop. 1996. The reproduction of anglerfish Lophius piscatorius Linnaeus from the north-west coast of Scotland. J. Fish Biol. 49:18-39.

Armstrong, M. P., J. A. Musick, and J. A. Colvocoresses. 1992. Age, growth, and reproduction of the goosefish Lophius americanus (Pisces: Lophiiformes). Fish. Bull. 90:217-230.

Artegiani, A., D. Bregant, E. Paschini, N. Pinardi, F. Raicich, and A. Russo.

1997a. The Adriatic Sea general circulation. Part I: Airsea interactions and water mass structure. J. Phys. Oceanogr. 14:1492-1514.

1997b. The Adriatic Sea general circulation. Part II: baroclinic circulation structure. J. Phys. Oceanogr. 14:1515-1532.

Brown-Peterson, N. J., D. M. Wyanski, F. Saborido-Rey, B. J. Macewicz, and S. K. Lowerre-Barbieri.

2011. A standardized terminology for describing reproductive development in fishes. Mar. Coast. Fish. 3:52-70.

Carbonara, P., R. Zupa, and M. T. Spedicato.

2005. Occurrence of a spawning female of Lophius budegassa Spinola, 1807 in the Salerno Gulf. Biol. Mar. Mediterr. 12:488-491.

Carlucci, R., F. Capezzuto, P. Maiorano, L. Sion, and G. D'onghia.

2009. Distribution, population structure and dynamics of the black anglerfish (Lophius budegassa) (Spinola, 1987) in the Eastern Mediterranean Sea. Fish. Res. 95:76-87.

Caruso, J. H.

1985. The systematics and distribution of the lophiid anglerfishes: III. Intergeneric relationships. Copeia 1985:870-875.

1986. Lophiidae. In Fishes of the North-eastern Atlantic and the Mediterranean (P. J. P. Whitehead, M.L. Bauchot, J.-C. Hureau, J. Nielsen, and E. Tortonese, eds.), p. 1362-1363. UNESCO, Paris.

Colmenero, A. I., J. Aguzzi, A. Lombarte, and A. Bozzano.

2010. Sensory constraints in temporal segregation in two species of anglerfish, Lophius budegassa and $L$. piscatorius. Mar. Ecol. Prog. Ser. 416:255-265.

Crozier, W. W.

1985. Observations on the food and feeding of the anglerfish, Lophius piscatorius L., in the northern Irish Sea. J. Fish Biol. 27:655-665.

Duarte, R., M. Azevedo, J. Landa, and P. Pereda.

2001. Reproduction of anglerfish (Lophius budegassa Spinola and Lophius piscatorius Linnaeus) from the Atlantic Iberian coast. Fish. Res. 51:349-361.

Dupouy, H., R. Pajot, and B. Kergoat.

1984. Study on age and growth of the anglerfishes, Lophius piscatorius and L. budegassa, from nord-east Atlantic using illicium. Rev. Trav. Inst. Pech. Marit. 48:107-131.

Everly, A. W.

2002. Stages of development of the goosefish, Lophius americanus, and comments on the phylogenetic significance of the development of the luring apparatus in Lophiiformes. Environ. Biol. Fishes 64:393-417.
Fariña, A. C., M. Azevedo, J. Landa, R. Duarte, P. Sampedro, G. Costas, M. A. Torres, and L. Cañás.

2008. Lophius in the world: a synthesis on the common features and life strategies. ICES J. Mar. Sci. $1272-1280$.

Feinberg, M. N.

1984. All head and mouth. Nat. Hist. 93:28-33.

Fulton, T. W.

1898. The ovaries and ovarian eggs of the angler or frogfish (Lophius piscatorius), and of the John Dory (Zeus faber). Sixteenth Annual Report of the Fishery Board for Scotland Part III:125-134.

García-Rodríguez, M., P. Pereda, J. Landa, and A. Esteban. 2005. On the biology and growth of the anglerfish Lophius budegassa Spinola, 1807 in the Spanish Mediterranean: a preliminary approach. Fish. Res. 71:197-208.

Hislop, J. R. G., A. Gallego, M. R. Heath, F. M. Kennedy, S. A. Reeves, and P. J. Wright.

2001. A synthesis of the early life history of the anglerfish, Lophius piscatorius (Linnaeus, 1758) in northern British waters. ICES J. Mar. Sci. 58:70-86.

Hunter, J. R., and S. R. Goldberg.

1980. Spawning incidence and batch fecundity in northern anchovy, Engraulis mordax. Fish. Bull. 77:641-652.

Iorga, M. C., and M. S. Lozier.

1999. Signatures of the Mediterranean outflow from a North Atlantic climatology: 1. Salinity and density fields. J. Geophys. Res. 104:25985-26009.

La Mesa, M., and F. De Rossi.

2008. Early life history of the black anglerfish Lophius budegassa Spinola, 1807 in the Mediterranean Sea using otolith microstructure. Fish. Res. 93:234-239.

Landa, J., R. Duarte, and I. Quincoces.

2008a. Growth of white anglerfish (Lophius piscatorius) tagged in the Northeast Atlantic, and a review of age studies on anglerfish. ICES J. Mar. Sci. 65:72-80.

Landa, J., I. Quincoces, R. Duarte, A. Fariña, and H. Dupouy. 2008b. Movements of black and white anglerfish (Lophius budegassa and L. piscatorius) in the northeast Atlantic. Fish. Res. 94:1-12.

Laurenson, C. H

2006. A note on the development of the embryos of anglerfish Lophius piscatorius. J. Fish Biol. 68:1287-1290.

Laurenson, C. H., and I. G. Priede.

2005. The diet and trophic ecology of anglerfish Lophius piscatorius at the Shetland Islands, UK. J. Mar. Biol. Assoc. U.K. 85:419-424.

Leslie, R. W., and W. S. Grant.

1990. Lack of congruence between genetic and morphological stock structure of the southern African anglerfish Lophius vomerinus. S. Afr. J. Mar. Sci. 9:379-389.

Maravelias, C. D., and C. Papaconstantinou.

2003. Size-related habitat use, aggregation patterns and abundance of anglerfish (Lophius budegassa) in the Mediterranean Sea determined by generalized additive modelling. J. Mar. Biol. Assoc. U.K. 83:1171-1178.

Muñoz, M., M. Casadevall, and S. Bonet.

2002. Testicular structure and semicystic spermatogenesis in a specialized ovuliparous species: Scorpaena no tata (Pisces, Scorpaenidae). Acta Zool. 83:213-219.

Murua, H., G. Kraus, F. Saborido-Rey, P. R. Witthames, A. Thorsen, and S. Junquera.

2003. Procedures to estimate fecundity of marine fish species in relation to their reproductive strategy. J. Northwest Atl. Fish. Sci. 33:33-54. 
Negzaoui-Garali, N., and M. Ben Salem.

2008. Morphological characters and meristic counts in two anglerfishes, Lophius budegassa and L. piscatorius (Osteichthyes: Lophiidae) from Tunisian coastal waters (central Mediterranean). Ann. Ser. Hist. Nat. 18:17-26.

Negzaoui-Garali, N., M. Ben Salem, and C. Capapé.

2008. Feeding habits of the black anglerfish, Lophius budegassa (Osteichthyes: Lophiidae), off the Tunisian coast (central Mediterranean). Cah. Biol. Mar. 49:113-122.

Pavlov, D. A., N. G. Emel'yanova, and G. G. Novikov. 2009. Reproductive dynamics. In Fish reproductive biology: implications for assessment and management (T. Jakobsen, M. J. Fogarty, B. A. Megrey, and E. Moksness, eds.), p. 48-90. Blackwell Publ. Ltd., West Sussex, UK.

Pope, J. A., A. R. Margetts, J. M. Hamley, and E. F. Akyuz. 1975. Manual of methods for fish stock assessment. Part III. Selectivity of fishing gear, 46 p. FAO Fisheries Technical Paper No. 41, Revision 1. FAO, Rome.

Preciado, I., F. Velasco, I. Olaso, and J. Landa.

2006. Feeding ecology of black anglerfish Lophius budegassa: seasonal, bathymetric and ontogenetic shifts. J. Mar. Biol. Assoc. U.K. 86:877-884.

Sánchez, F., and J. Gil.

2000. Hydrographic mesoscale structures and Poleward Current as a determinant of hake (Merluccius merluccius) recruitment in southern Bay of Biscay. ICES J. Mar. Sci. 57:152-170.

Trippel, E. A., O. S. Kjesbu, and P. Solemdal.

1997. Effects of adult age and size structure on reproductive output in marine fishes. In Early life history and recruitment in fish populations. Fish and Fisheries Series 21 (R. C. Chambers, and E. A. Trippel, eds.), p. 31-62. Chapman \& Hall, London.

Tsimenidis, N. C. 1980. Contribution to the study of the angler-fishes Lophius budegassa Spinola, 1807 and L. piscatorius L., 1758 in Greek seas. Inst. Oceanogr. Fish. Res. (Athens) Spec. Publ. 4:180-190.
1984. The growth pattern of otoliths of Lophius piscatorius L., 1758 and Lophius budegassa Spinola, 1807 in the Aegean Sea. Cybium 8:35-42.

Tsimenidis, N. C., and J. C. Ondrias.

1980. Growth studies on the angler-fishes Lophius piscatorius L., 1758 and Lophius budegassa Spinola, 1807 in Greek waters. Thalassografika 3:63-94.

Ungaro, N., G. Marano, R. Auteri, A. Voliani, E. Massutí, M. García-Rodríguez, and K. Osmani.

2002. Distribution, abundance and biological features of anglerfish (Lophius piscatorius and Lophius budegassa) (Osteichthyes: Lophiiformes) in the Mediterranean Sea. Sci. Mar. 66:55-63.

Velasco, F., J. Landa, J. Barrado, and M. Blanco.

2008. Distribution, abundance, and growth of anglerfish (Lophius piscatorius) on the Porcupine Bank (west of Ireland). ICES J. Mar. Sci. 65:1316-1325.

Wallace, R., and K. Selman.

1981. Cellular and dynamic aspects of oocyte growth in teleosts. Am. Zool. 343:325-343.

West, G.

1990. Methods of assessing ovarian development in fishes: a review. Mar. Freshw. Res. 41:199-222.

Woodroffe, D. A., P. J. Wright, and J. D. M. Gordon.

2003. Verification of annual increment formation in the white anglerfish, Lophius piscatorius using the illicia and sagitta otoliths. Fish. Res. 60:345-356.

Yoneda, M., M. Tokimura, H. Fujita, N. Takeshita, K. Takeshita, M. Matsuyama, and S. Matsuura.

1998a. Ovarian structure and batch fecundity in Lophiomus setigerus. J. Fish Biol. 52:94-106.

1998b. Reproductive cycle and sexual maturity of the anglerfish Lophiomus setigerus in the East China Sea with a note on specialized spermatogenesis. J. Fish Biol. 53:164-178.

2001. Reproductive cycle, fecundity, and seasonal distribution of the anglerfish Lophius litulon in the East China and Yellow seas. Fish. Bull. 99:356-370. 